\title{
LITERATURE FOR 1912 ON THE BEHAVIOR OF ANTS AND MYRMECOPHILES
}

\author{
WILLIAM M. MANN \\ Bussey Institution, Harvard University
}

Miss Andries (I) made a detailed study of the taxonomy, biology and development of the German species of flies of the genus Microdon, which in their larval and pupal stages live in ant nests. The species studied (MI. rhenamus, mutabilis and eggeri) live most commonly with species of Formica, though the forms of eggern were found also with Lasius. Fertilized females of the fly readily oviposited on bark, inserting the oripositor into cracks. About one hundred and fifty eggs are laid, five to eighteen in a lot. These hatch in about twelve days. The larvae are not unlike certain slugs, and in fact were described by some early writers as mollusks. They crawl slowly about in the nest, secreting from the mouth a fluid that keeps the under side of the body moist. The food habits are not understood. Andries thinks that they feed on the regetable moisture in the nest, as no solid food was found in any of the specimens sectioned. The relationship of the fly in its different stages to the ants is not well understood. It was formerly supposed by Wasmann that the larrae were treated like big Coccidae. Those kept by Andries were entirely ignored by the ants, and it was noted that when nests in the field were disturbed the ants removed their brood to a place of safety, while the Microdon larvae remained behind unnoticed. Wasmann has observed the ants lick the golden hairs of freshly emerged adults, but Andries notes that the adults, both in the field and in observation nests, were treated inimically by the ants, which seized them by the legs and wings. She succeeded in bringing growing larvae through to the adult stage apart from ants, and does not believe that Miciodon is closely dependent upon its host.

Biun (3), after numerous experiments on the colony forming habits of Formica, believes that the higher acervicolous species in the genus are descended not only morphologically, but also 
biologically, from the jusca group, that is, trom a fusca-like ancestor. In fisca, the habit of two or more queens jointly forming a colony-" pleometrosis" of Wasmann-sometimes occurs, but with this ant it is merely an occasional method of colony-formation. The typical method, according to which the individual female after the marriage flight starts he1 colony unaided, is most general. In $F$. pratensis and $F$. rufa pleometrosis is more fully developed, and is of use in splitting up the colony into branches, and by means of these extending the colony in the near vicinity. Bi un considers that the great success of rufa as a species is accounted for by this habit of colony splitting. The origin of this bianch-forming habit has been explained by Wasmann as an adaptation to special methods of life. Rufa and pratensis have become adapted to life in certain ecological situations, in which they are sporadically very abundant, in contrast to other more widely adaptable ants such as Lasius, Tetramorium, etc., which occur in nearly all kinds of localities. The special vegetative conditions to which rufa and pratensis are adapted are exhausted atter the long residence of an ant colony in one place, and then it is beneficial to be able to split the colony, and enable it to spread in the immediate vicinity where the conditions are the same, rather than to send off swarms to less favorable localities. This branching can be accomplished by the raising of reserve queens, which produce branch nests for the excess workers. Each season, during the time of flight, large numbers of sexual forms are held back in the nest. This habit has gradually modified the normal instinct of the female, the mneme of which has thus been weakened ("buszt an Frische ein"). After the marriage flight the normal instinct of an ant queen is to dig a hidden chamber, but in rufa, whose ancestors were continually surrounded by workers, because of the inherited engrammes, there is developed a strong "social desire," which drives it to seek worker society. Here there are three possibilities. The temale may seturn to one of the peripheral nests of the mother colony, becoming in reality parasitic on the members of her own colony, which is the first stage in social parasitism. Many do not reach their own colonies, but find other nests of the same species, or of another race and take up with them, while a comparatively small number, reaching rufafree ground, enter the nests of strange species. This latter is the 
last stage of social parasitism. It is thus shown that the social parasitism of rufa is derived trom pleometrosis through a number of steps. That all of these intermediate stages occur in this species shows that rufa must still stand in a primitive condition as far as social parasitism is concerned. Wheeler has had a tendency to consider rufa as an obligatory social parasite (both Brun and Wasmann eridently fail to understand his position in regard to this matter), but Brun agrees with the theory of Wasmann, and furthermote endeavors to strengthen this view by an appeal to the engramme-theory of Semon, that pleometrosis necessatily causes degeneration and final loss of the colonyforming instinct, thereby giving a psychological foundation to the theory. From the standpoint also of paleontology, morphology and geographical distribution Wasmann's theory seems to be correct. Brun agrees with Wasmann also in considering that $F$. sanguinea approaches the rufa type biologically, and therefore has been derived trom a rufa-like form. Emery, Viehmeyer and Wheeler, who have opposed Wasmann's theory and to some degree" upset it, have maintained that, "A robber cannot be derived from a parasite," hence a robber ant, during its development, can never traverse the stage of social parasitism, cven as a facultative one, as in rufa. They all look upon the pupal robbing habit as a distinctive mode of colony tor mation from which dulosis is supposed to have developed on one hand and social parasitism on the other, thus accepting the robber-female theory of Emery. As Wasmann himself has answered many of the attacks on his theory, Brun does not undertake to go into all of the criticism, but defends Wasmann on the ground that Viehmeyer must have misunderstood him. Wasmann never contended that the predatory stage of sanguinea is derived from a parasitic stage. The sanguinea group does not go back to rufa, but comes from a rufa-like form, which had a tendency toward pleometrosis and branch-colony formation, and thereby lost its ability to form independent colonies. From such ancestors there branched off a particularly viable race with high psycho-plastic tendencies, part of whose females, after the ancient manner, allow themselves to be taken up by the same species; others, "having higher attainments," since they could not accomplish this, took to robbing pupae, or made up to a colony founding fusca queen, which they later robbed or mur- 
dered. Regarded in this way, the familiar statement that parasites cannot become robbers loses its significance as an argument against the derivation of sanguinea from rufa-like ancestors, for sanguinea comes not from rufa, but from a rufa-like type, with a loss of colony-foundation instincts, which does not involve parasitism. Neither does this mean degeneration, but rather a high development, as in the present day rufa. Viehmeyer's opinion that these species are doomed to extinction seems "curious" to Brun, considering the immense size of the colonies of $r u f a$; as "curious" as the organic and psychical degeneration which he thinks he finds in the high psycho-plastic endowment of sanguinea. In saving the psycho-phylogeny of his robber stages, Viehmeyer assumes that the females of sanguinea originally took part in the robber raids of their colonies, but this opinion is too uncertain to be taken seriously in the discussion. Brun concedes Wasmann's derivation of dulosis in Formica from a facultative adaption stage to be the weakest part of his theory. The apparent analogy of permanent dulosis and temporary parasitic colony foundation will not stand strong criticism, because we do not know that the colonies are exclusively founded with the aid of fusca. We can account for the social parasitic condition of rufa only by assuming a condition involving the loss of the ability to establish a colony unaided, and this loss could have been due as directly to the pupalrobbing habit as to obligatory social parasitism. Wasmann did not mean that a subparasitic condition was a step toward dulosis, any more than he wished to deduce the already developed social parasitism from dulosis. He considers dulosis in sanguinea a direct engraphic influence. Through the presence of fusca in the nest the young sanguineas are influenced to raise the fusca pupae obtained by raids, and care only for those whose smell is similar to their own. This psychological reason of Wasmann does not seem to Brun to hold, for the tendency of sanguinea is not limited to fusca pupae, but extends also to allied species. This, Brun explains, is a fixed, inherited association from analogy. The workers in colonies not socially parasitic often show just as strong a tendency toward dulosis.

Brun is not inclined towards Wasmann's hypothesis of the origin of dulosis in Formica from facultative social parasitism, 
but does lean toward his theory that the social parasitic stages were derived flom a rufa-like form.

Brun (3) believes that the theory of the mixture of odors, which has been used to explain, in a purely physiological way, the tolerance of one species toward another in the artificial alliances of certain species of ants, must be given up, as entirely untenable. These artificial alliances do not depend upon the mixture of odor, but depend entirely upon complex associative brain processes, especially in the realm of individually acquired mnemic engrammes.

Cornetz (5) believes that the apparent cooperation of several ants in moring particles of food too laige to be handled by a single individual is simply the result of the stimulus that causes the solitary ant to return home. When an ant starts on a foraging trip it receives, in some manner, an impression that later guides it back to the nest. When it finds a morsel of food it takes it, and returns by an almost direct route. Several ants, having hold of a morsel too large for a single one, are each guided by this direction-sense toward the nest, with the result that the combined efforts of many holding and pulling the piece of food are used to bear it. This gives at first sight the impression of mutual aid, but is in reality only "a fortuitous coincidence of purely individual actions." There is even actual hindrance to one another when many have hold of the same morsel. Likewise, other actions at first sight mutualistic are believed to be simply the result of individual activity or of a certain tendency toward imitation, comparable to the flocking of sheep. Thus, Cornetz saw an isolated worker digging at a new nest some distance away from the principal nest. In another instance seven workers were engaged in working at a gallery far from the nest. These carried eggs, larvae and even adults from the original formicary, in which, however, most of the colony remained. This division was in no sense beneficial to the entire community, but was probably the result of several workers following one that had started the new gallery. As the worker is merely an undereloped female, the tendency to establish a new colony is not surprising, as often other female characters are more or less developed in individual workers, even parthogenetic reproduction, and the nest-forming habit is typically female. When one worker begins to dig a new nest, others cooperate 
through imitation. Cornetz does not believe that the social cooperation of ants is altogether a result of indiridual action, but points out that there may be much less mutualism than is generally believed.

Cornetz (8) believes from a study of Myrmecocystus that this ant has, to a greater or less extent, an impression of the territory immediately surrounding the nest entrance, but that this memory is inconstant and of short duration, especially when based upon the visual sense. When the memory is olfactive it may persist for a long timke.

Cornetz (10) compares the sense of direction of the rat and the ant. The rat observed by Szymanski (Essais pour exprimer par des nombres le rapport entre des stimulants de gentes differents. Archiv. f. d. ges. Physicl., Bonn, 19r2) when liberated in a box containing a pan of water wandered about until it found this, but each succeeding time, by the "dropping of useless movements," shortened the distance traveled, till it finally went directly to the water. On each trip the rat had rerived impressions that had been received on the previous trips. The ant, on the other hand, is guided by an impression receired on each outgoing journey, and rerived on the homegoing route. To what extent the ant is able to remember a direction "to the right" or "to the left" is still completely unknown, but Cornetz ventures the hypothesis that the ant does not need a memory, but possesses "en soi" a sense of direetion. This he believes to be not at all impossible, though hard to conceive.

Cornetz (Ioa) experimented on the estimation of distance in ants. Workers of Pheidole pallidula away from the nest were decoyed by little pieces of cheese on to a knife blade, and taken to a point at a short distance away. When the ant dismounted from the blade it set out in a line parallel and opposite to the outgoing trail, reversing the direction of march in the manner usual to ants, but owing to the change of the starting point, not in the direction of the nest. Cor netz made careful comparison of the distance traveled on the wrong trail, and the distance to the nest if the ant had not been moved to another starting point. Where both trails were on the same kind of material, there was an erior of from one-tenth to one-fifth of the distance, though one ant erred by three-fifths, which is an abnormal amount. When the trails were different (one on cement and the other on 
bricks) the error ranged from one-sixth to nine-tenths of the distance. On a longer journey the error was still greater. The start in a direction the rererse of the line of march in the outward journey, even when not toward the nest, and on different kinds of material, offers additional evidence that the homegoing ant is influenced little by sight or the sense of touch.

Cornetz (7) repeated the experiment of turning a disc on which an ant (Myrmecocystus (Cataglyphis) bicolor) was feeding. The disc in this case was a large plate, containing sugar as bait. Each time the ant, when it was through feeding and had a load of the food, immediately oriented itself in the direction toward its nest-entrance, though the disc had been turned 180 or $270^{\circ}$. The podometric sense, according to Cornetz, will not explain the return of the ant, both because "a podometer is no compass" and because the route taken by the returning insect is not the same as the outgoing trip. He answers the question, "How do ants find their way," by stating that they do not find their way. It is not necessary. They are guided by some internal impression received on the outgoing trip. Just what this is, he does not pretend to understand, but he believe that it is neither touch, smell nor sight, nor a combination of these, but something peculiar, possessed by all ants.

Crawley (II) studied parthenogenetic reproduction in Lasius niger, with colonies confined in artificial nests. It has long been known that under certain conditions, generally when no queen is present, worker ants are capable of laying unfertilized eggs that develop parthenogenetically. Some observers have concluded that only males are produced from these worker-laid eggs, but in 1902 a queenless colony of Lasius niger, kept under observation by Reichenbach, reared some three hundred workers and two or three dozen males from unfertilized eggs, and Wheeler in 1903 recorded similar results obtained by Mrs. Comstock with Lasuis niger var. americanus. On the other hand, Janet, who made careful experiments with no less than thirty queenless colonies under varied conditions, succeeded only in getting males. Into a nest of Lasius niger that had lost its queen through accident, Crawley placed a queen of Lasius umbratus which was immediately adopted. Although this queen deposited many fertile eggs, for two years none of the young reached maturity, as they were eaten by the niger workers; thereafter the few 
that did mature were immediately killed and eaten, or fed to the other larvae. During this time sereral hundred niger workers reached maturity. In another similarly composed colony the results were the same. During four years no males were produced. A third nest again containing a queen of L. umbratus and niger workers, with no brood at the start, produced only nger workers, normal in all respects except that they were somewhat undersized. Twelve workers were carefully dissected in order to ascertain if a receptaculum seminis was present. This was not found, so the experiment confirms that of Reichenbach and shows that in parthogenetic reproduction by wolker ants, workers as well as males may result.

Crawley (12) found in England a colony of the parasitic ant Anergates atratulus in a Tetranorium caespitum nest. No sexual forms of the latter species were present. The male Anergates is wingless, and copulation takes place in the nest. The queens kept by Crawley removed their wings shortly after copulation, and made no attempt to leave the colony, but each queen seized a Tetramorium worker by the antennae and kept hold of it for hours. This habit may be useful in getting the queen into a strange nest, and may hare for its object the acquisition of the odor of the Tetramorium. A colony of the latter ant that had adopted a newly fertilized Anergates queen, killed off all the sexual torms of its own species in the nest, including two dealated queens.

Donisthorpe (I3) found colonies of Leptothorax acervorum and Myrmica laevinodis beneath the same stone. When the nest was disturbed they showed no antagonism toward each other, and if they picked up each other's larvae or pupae they put them down again. Small larvae of the fly Microdon mutabilis kept in an artificial nest with Formica fusca gtew to a large size without being fed by the ants or feeding on the honey provided for them. When the ants moved, the Microdon followed them very slowly. It is evident that they feed on the droppings and pellets rejected from the buccal chamber of the ants. Antennophorus uhlmanni, which lives attached to Lasius umbratus, was observed to move to one side of the ant's head in order to permit it to feed.

Donisthorpe and Crawley $\left(\mathrm{I}_{4}\right)$ made a number of experiments on the founding of colonies by queens of Lasius fuliginosus. It 
had long been supposed that this species was a temporary social parasite of Lasius umbratus and its varieties. A queen of the former species placed in umbratus colonies was not attacked at once, as is generally the case when a queen ant is introduced into a strange colony, but in some instances was attacked later on. When some part of her body was being held by an inimical worker, she endeavored to conciliate it by caressing with her antennae, and often succeeded. Some of the queens on which experiments were made were persistently molested and finally killed, but several were fully adopted and had larrae and pupae at the time the record of the experiment stopped. This shows that fuligmosus is a temporary social parasite of umbratus, which itselt is parasitic in turn on $L$. niger. Several pupae of niger were placed in a nest of umbratus, in order to ascertain if the latter had any friendly instincts remaining toward the species in a colony of which it had begun its existence. The pupae were carried about, but were left too long before being opened so that most of the ants that emerged were crippled. These wee bullied by the umbratus, but two perfectly healthy individuals were living in the nest, unmolested, at the time of writing.

Emery (15) observed that the eggs laid by workers of a harresting ant. Messor barbaris minor, produced only males. The larvae were different in appearance from those which produced females and workers, so he concludes that sexual dimorphism is apparent also during lav val stages. The same species was offered oats which had germinated and from which the husks had been 1emoved. These were chewed by the ants till they became a ductile mass, from which the nutritive portions had been extracted. Dried oats, not germinated, were put in the nest. The ants ate first the embryo and the end of the gtain where this was located, a habit that had been noticed by the ancients and which was mentioned by Plutarch. When the embryos and the farinaceous parts of the seed were separated and each ground up and made into a paste by the addition of water, the ants showed a decided preference for the paste made from the embryonic portion, especially when it was the more humid of the two. The cutting of the radicles of the seed by grain-storing ants may be the result of this fondness for the germinal portion. Italian paste in small ring-shaped pieces 
which had been carefully weighed was placed before the ants in their nest, and the discarded refuse and pellets were afterwards weighed and a chemical analysis of the substance was made both before and after the ants had had access to it, so as to ascertain just what proportion of the total quantity and what nutritive properties of each had been consumed. Some of the paste was fed by the ants to their larvae after being softened by malaxation. The larvae ate this readily, so Emery decided that the making of "larval bread" as described by Neger, is not necessary. The workers consumed about $7.3 \%$ of the starch in the paste in order to digest it or give it as food to the larvae. The quantity of non-starchy foods was not ascertained, but Emery assumes that the nitrogenous portions are more important than statch.

The harvesting ants are descended from insectivorous forms, which have taken up the grain-storing habit as an adaptation to life in the desert, on steppes, etc., where during parts of the year insect food is scarce. Seeds can be stored and kept, which is not true of insect food. Emery notes that the species studied, though a typical harvesting ant, never refuses insect food.

Ernst (r6) placed a number of queens of Lasius flavus in an artificial nest. Eggs laid by these developed rather slowly, but produced larvae and imagines. The latter, while yet callows, disappeared, and Ernst found portions of their bodies and in the same place two individuals of the mite, Laelaps oophrlus, which must have been introduced into the nest on the bodies of the females. The number of mites increased rery rapidly till the bottom, sides and covers of the nest, twelve by nine $\mathrm{cm}$. in dimensions, were swarming with them. Many were among the eggs and even crawled upon the ants' heads, from which they were dislodged by rigorous shaking. A living callow lying on the bottom of the nest was seen to be attacked by numerous mites, most of which were on the thorax and legs. The next morning only portions of the ant were found, the probability being that the mites had taken it to pieces, though this was not actually seen. The mites in the nest died off very suddenly, so observations could not be continued. Ernst, from a long series of observations, believes that ants are capable of forming attachments to one another. Though an ant recognizes and is friendly 
to others of the same colony it does not generally associate with one particulat individual more than with others, but Ernst observed that two isolated ants showed an attraction for each other, remaining together much of the time, and when one died the other showed signs of much uneasiness. In the case of two females and a worker of Tapinoma erraticum which were kept isolated, the former seemed much disturbed at the death of the latte1, licking and feeling of the body. These actions were more pronounced in one of the females than in the other. A female of Formica rufibarbis, after killing two females of $F$. pratensis, received a third without signs of hostility, and the two lived amicably together. Different species of ants val $y$ in their aptitude tor making friends, and the temales form the association more quickly than the males. Ernst observed a Dipteron, Farnia manicata, in company with ants, in the act ot "milking" aphids and sipping up the drop of exuded liquid. The fly stroked the gaster of the aphid with its forefeet, which are provided with a brush of hairs.

Besides ants and this interesting dipteron, a Lycaenid butterfiy in Ceylon is known to milk aphids.

Hungerford and Williams ( 7 ) in Kansas observed that the great majority of nests of Pogonomymex occidentalis have their openings on the southeast side or more toward the east. A heliotropic influence is suggested.

A special disgust was shown by the workers toward certain Scaraboeid beetles. When one of these was placed on the nest it was attacked by as many as ten workers, and when it had ceased struggling was carried to a distance of ten or twelve feet from the cone. The ant was seen carrying the myrmecophilous beetle Cremastocheilus saucius.

Hunter (I8) notes that in fields intested with the agricultural ant, Pogonomyrmex harbatus var. molefaciens, the plants in a circle just outside the cleared areas of the nest grow with increased luxuriance, a condition he thinks, caused hy the loosening of the soil through the underground tunnels of the ants, which has somewhat the effect of deep plowing. This increased growth is, in a way, compensatory for the cleared areas which the ants make, and though it does not entirely offset the loss caused by them, reduces the economic importance of the insect. 
The actual damage caused by these ants is said by Mr. J. D. Mitchell, who has made many observations on the species, to be greatly overestimated.

Von Ihering (19) in Brazil found nests of the army ant, Eciton coecum, deep in the earth beneath termite nests. It has long been supposed that ants of the genus Eciton do not make permanent nests, but move about from place to place. At times clusters have been found with many workers, larvae and pupae, and often a female, and these have been considered temporary nests. Von Ihering thinks that these are swarms. The female, blind and wingless, is not capable of founding a colony unaided, after the manner of most queen ants, and new colonies are established by means of a "swarm," composed of a queen and numerous workers, often accompanied by males. Sometimes males of different species are present, and von Ihering thinks that hybridization may not be uncommon among the species of Eciton.

Jacobson (20) in Java observed the larvae of the butterfly, Hypolycaena erylus, which is attended by the ant Oecophylla smaragdina. Both of these insects were common on the rubiaccous plant Banguersia spinosa. The butterfly lays her eggs on a plant tenanted by the ants. These attend the larra, and by caressing it receire a drop of exuded liquid which is eagerly lapped up. A considerable amount of this liquid is secreted by a single larva during the course of a day. Larvae under observation, not attended by ants, became listless and later died, so there is evidently a close though not well understood, symbiotic relation between the two insects. The pupae also were cared for and licked, though in them there is no erident food supply for the ants.

Lea $(2 \mathrm{I})$ in a supplement to a paper on the Australian and Tasmanian Coleoptera inhabiting or resorting to the nests of ants, bees and termites (Proc. Roy. Soc. Victoria, Vo1. XXIII, (Nert Series, pt. I, Igro.)) lists and describes a large number of myrmecophilous and termitophilous beetles. Through the energies of Mr. Lea and his co-workers the rery rich ant-nest fauna of Australia and Tasmania is becoming comparatively well known. It is an interesting fact that the ponerine ants of those islands, especially Ectatoma metallicum, harbor a preponder number of the inquilines. 
Leonard (22) observed workers of Messor andrei after a heavy rain carrying out members of the colony which were covered with mud and quite lethargic After these had remained in the warm sunshine for a time they returned into the nest. Leonard assumes that they had suffered from the wetting and the nestmates had carried them out where they might revive.

Lucas (23) notes that in a colony composed of about twenty workers, without a queen, of Formica fusca in an artificial nest, eggs were deposited parthogenetically. These were either eaten or neglected by the ants, so none developed.

Malloch $(25)$ in a monographic rerision of the dipterous family Phoridae lists sixteen North American species that are known to be associated with ants. Most of these are parasitic, though one species, Metopina pachycondylae, is known to live as a commensal with Pachycondyla harpax in Texas.

Mann (26) observed the Proctutrypid Mimopria ecitonophila, with Eciton hamatum, the host ant. The parasite runs along.with the army of workers in an ant-like manner, and is sometimes picked up and carried hy the ecitons.

Mann (27) found in Brazil a Ponerine ant, Odontomachus affinus subsp. mayi, living in company with Dolichoderus debilis var. rufescens, in an arboreal earthy nest constructed by the latter species. Odontomachus generally nests in damp places such as beneath stones or logs. In the earthy nest of Dolichoderus this variety finds a suitable arboreal envionment, and being a powerful, stinging ant, is very probably useful to the Dolichoder us in defending the nest.

Newcomer (28) in California studied the caterpillars of Lycaena fulla and L. pseudargiolus var. piasus in their relation to ants. The latter species in the third and fourth instars is very generally attended by Taprnoma sessile and Prenolepis imparis and occasionally by Crematogaster and Camponotus. An ant, on discovering a larva, proceeds to stroke its posterior segments with the antennae, and to feel about with its palpi. If the ant touches the evaginable organs of the eleventh segment it immediately becomes greatly excited and runs about as though irritated. The sharp projections on the setae of these organs evidently irritate the sensitive antennae, and thus act as a repellant when the caterpillar is not able to exude the liquid which the ant desires. A caterpillar may be disturbed several 
times by the ant before the slit on the tenth segment opens and the papilla which bears the drop of liquid is thrust out. The ant laps this up, while it is stroking the larva with its antennae. L. piasus emits a drop of the liquid about once every fifteen minutes. The stroking of the larva by the ants acts as a stimulus which causes either the ejection of the liquid or, in case the organs are not in a condition to exude, the eversion of the repellant organs of the eleventh segment.

Pieron (29) gives a general survey of the observations and experiments by various investigators on the problem of orientation in ants. As far back as 1745 , when Bonnet published on the subject, it has been known that the sense of smell plays an important rôle in guiding the ant back to its nest. Huber, Forel. Bethe and others have confirmed this, till there is no doubt as to its truth, and Santschi has recently shown that certain species by means of touching the ground with the tip of the gaster actually make an odoriferous "intentional" trail. The differences in this trail, which naturally varies in intensity close to and remote from the nest, are appreciated by the "topochemic sense" (Forel) and are therefore raluable in orienting the home-going ant. Odor plays a more important rôle with those ants which have a collective trail, except in some forms, like the wandering Ecitons and the slave-making Poly ergus, the armies of which do not return directly by the outgoing trail. In the case of isolated foraging ànts, in the environs of the nest. it is probable that sight, smell and touch are all employed, diflerent forms of ants varying in the degree in which these varicus senses are used. Thus Lasius is considered by Piéron to be an olfactive type, Formica and Camponotus visual types and Messor a muscular type. Orientation at a distance from the nest opening has been explained in a number of ways, and it is probable that the muscular memory and the influence of the light are both important elements, though neither fully explains the problem. The ant does not exactly ietrace its steps and probably makes more movements on the out-going than on the returning trip, which may cause considerable error in locating the nest again, while the impression given by the light is obviously received only by diurnal species. Piéton points out that the agricultural ants-Messor-of Erytrea stop 
foraging at the close of the day, and asks if this could be caused by the need of the direct influence of the light for guidance.

In addition to light and the muscular memory there must be some other influence. Two hypotheses are suggested. Either the ant possesses a magnetic sense, or there is some internal organ that records sensations made in describing angles on the outgoing trail.

Ruschkamp ( $3 \mathrm{I})$ tound in Holland the first stage of an adoption-colony of Formca rufa by $F$. fusca. A single dealated rufa queen was in a nest occupied by a weak fusia colony. No fusca queen was present. This mixed colony was placed in an artificial nest and observed for some time. The alien queen had been completely adopted.

Wasmann (32) describes an extraordinar y Staphylinid beetle, found in West Africa with the army ant, Dorylus (Annoma) nigricans subsp. sjostedit. This beetle, named Mimanomma spectrum, is a most striking example of mimicry, with greatly elongated thorax, short, thick antennae and ant-like abdomen. The latter has the first two segments small and constricted, resembling in form the petiole and post-petiole of Annoma, and the general form of the body is more ant-like than even the Staphylinid Mimeciton pulex, hitherto the most remarkable ant mimic among the beetles. A number of species of the family Staphylinidae are exceedingly similar in form to the ants with which they live; also some of the parasitic Hymenoptera and even Diptera which live with ants resemble them closely, but none are so greatly modified as this new species described by Wasmann.

Wasmann (33) gives a list of some forty species of inquilines recorded from the nests of one species of ant, Solenopsis geminata. These represent the orders Coleoptera, Diptera, Hymenoptera, Thysanura, Acarinar and Diplopoda. A number of guests of East Indian species of Pheidole are listed also, and several new species of myrmecophilous Coleoptera are described.

Wasmann considers that the adaptations to myrmecophily in the European lady-beetle, Coccinella distincta, present a Darwinian paradox. The larva of this beetle lives unmolested in the nests of species of Camponotus and Formica, where it feeds on scale insects which are fostered by the ants and from which 
the ants receive part of their food supply, and is therefore inimical to the welfare of the ant community. Such an association, Wasmann thinks, could not have been brought about by natural selection. That selection is a factor in evolution is admitted, but it does not play a leađing rôle.

Wheelet (34) describes a peculiar coenobiotic association which he found in Arizona. Five or six organisms cooperate to form this. The oak, common in the Huachuca Mountains, was heavily infested with the mistletoe. Larvae of a weevil had made their borings in this, and these were tenanted by colonies of the ant Cremastogaster arzionensis. On the inside of the ant galleries were numerous scale insects, later described by Cockerell as Pseudococcus phoradnedru, which slowly kill the mistletoe. Thus the ant, which fosters scales injulious to the mistletoe which is a serious parasite of the live oaks and other trees, may be regarded as a useful forest insect.

7immer (35) records the finding of a nest of Lasius fuliginosus in a child's coffin which had been buried for about thirty years. The entire interior of the coffin was filled with carton made by the ants.

1. Andries, Maria. Zur Systematik, Biologie und Entwicklung von Microdon Meigen. Zeit. f. wiss. Zool., 103,300-361.

2. Brun, Edgar Ueber die Ursachen der kunstlichen Allianzen bei den Ameisen, en Problem der vergleichenden Psychologie. Zeit. $f$. wiss. Insektenbrol., 8, 334-.

3. Brun, Rubolf. Zur Peychologie der kunstlichen Allianzkolonien bei den Ameisen. Biol. Cent., 32, 308-322.

4. Brun, Rudolf. Weitere Beitrage zur Frage der Koloniegrundung bei den Ameisen, mit besonderer Berucksichtigung der Phylogenese des sozialen Parasitimus und der Dulosis bel Formica. Biol. Cent., 32, 151-180, 216-226.

5. Connetz, V. L'illusion de l'entraide chez la fourmi. Rev. des Idées, 15 Dec. $1912,1-12$.

6. Connetz, Victor. Ueber den Gebrauch des Ausdruckes "tropische" und uber den Charakter der Richtungskraft bei Ameisen. Arch. f. d. ges. Physiol., 147, 215-233.

7. ConNerr, V. Observations de fourmis recruteueses de l'espèce Myrmecocystus cataglyphis bicolor. Bull. Inst. gén. Psych., 12, 79-90.

8. ConNET, V. De la durée de la mémoire des lieux chez la fourmi. Arch. de Psychol., 12, 122-138.

9. Cornetz, 'V. Les fourmis voient-elles des radiations solaires traversant les corps opaques. Bull. Inst gén. psych., 12, 367-372.

10. Cornetz, $V$. Comparison entre la prise d'une direction chez un rat et chez une fourmi. Bull. Inst. gén Psych., 12, 357-366.

10a. Cornetz, V. Quelques observations sur l'estimation de la distance chez la fourmi. Bull Soc. Hist. Nat. de l'Afrique du Nord. Jan., 1912.

11. Crawley, W. C. Parthenogenesis in Worker Ants, with special reference to two colonies of Lasizes niger, Linn. Trans, Ent Soc. London, Feb. 10, 1912, $657-663$. 
12. Crawtex, I. C. Anergates atratulus Schenk., a British Ant, and the Acceptance of a female by T'etramorium caespitum, L. Ent. Record, Jour. I'a*., 24, 218-219.

13. Donisthorpe, H. ST. J. K. Myrmecophilous Notes for 1911. Ent. Record, 24, 4-10, 34-40.

14. Donisthorpe, ST. J. K. and Crawtex, W. C. Experiments on the Formation of Colonies by Lasius fuliginosus. Trans. Ent. Soc. London, Feb. 10, 1912. 664-672.

15. Emery, Carlo. Aleune esperienze sulle Formiche granivore. Rend. Sess. $R$. Acad. Sci. Ist. Bologna, 1912 , pp. 107-117.

16. Ernst, Christian. Neue Beobachtungen bei Ameisen. Biol. Cent., 32, 146153.

17. Hungerford, H. B , and Frañcis X. Williams. Biological Notes on some Fiansas Hymenoptera. Ent. Fews, 23, 241-260.

18. Hunter, W. D. Two Destructive Texas Ants. U. S. Dept. Agric. Circ. No. $148,1-7$.

19. von IHERING, $H$. Biologie und Verbreitung der brasilianischen Arten von Eciton. Ent. Mittheil, 1, No. 8, pp 226-235.

20. JACOBSON, EDw. Symbiose zwischen der Raupe von Hypolycaena crylus Godart und Oecophylla smaragdina Fab. Tijdschr. fur Entom., 55, 9-14.

21. LEA, A M. Australian and Tasmanian Coleoptera Inhabiting or Resorting to the Nests of Ants, Bees and Termites. Supplement. Proc. Roy. Soc Victoria, 25, (New Series), Pt. 1, 31-78.

22. Leonard, Percy. The Emmet Harvesters of Point Loma. The Theosophical Path., 2, No. 3, March, 1912, 215-216.

23. Lucas, Karl. Parthenogenese bei der grauschwarzen Waldameise (Formica fusca L ). Zeitschr f. wiss. Insehtenbiol., 8, 272-276.

24. Lusa, Edovard. Moeurs des Anomma. Monatsber. Ges. Luxcmburg. Naturfreunde, N. F. Jahrg. 3, 94-97.

25. Malloch, J. R. The Dipterous Insects of the Family Phoridae in the United States National Museum. Proc. U. S. Nat. Mus., 43, 411-529.

26. Mann, Willam M. The Stanford Expedition to Brazil, 1911. J. C. Brannek, Director Note on a Guest of Eciton hamatum Fabr. Psyche, 19, 98-100.

27. Mand, William M. The Stanford Expedition to Brazil, 1911. J. C. Branner, Director. Parabiosis in Brazilian Ants. (Contrib. Entom. Lab. Bussey Inst. Harvard Univ. No. 54). Psyche, 19, 36-41.

28. New comer, E. J. Some Observations on the Relations of Ants and Lycaenid Caterpillars, and a Description of the Relational Organs of the Latter. Jour. V. Y. Entom. Soc., 20,31-36.

29. Piéron, $H$. Le problème de l'orientation envisagé chez les fourmis. Scientia, $12,217-243$.

30. Praut, Menko. Ueber die Symbiose bei Ameisenpflanzen. Neuere Arbeiten zur Kritik der Theorie Schimpers. Monatsh. nat. Unterr., 5, 33-37.

31. Ruschкamp, F. Eine neue naturliche rufa-fusca Adoptionskolonie. Biol. Cent., 32, 213-216.

32. WASMANN, E. Mimanomma spectrum, ein neuer Dorylinengast des extremsten Mimikrytypus. Zool. Anzeig., 39, 473-481.

33. Wasmann, E. Neue Beiträge zur Kenntnis der Termitophilen und Myrmecophilen (No. 192). Zeit. i. wiss. Zool., 101, 70-115.

34. Whenler, Willtam Mopton Notes on a Mistletoe Ant. Jour. N. Y. Entom. Soc., 20, 130-134.

35. ZMmer, $C$. Nest von Lasius fuliginosus Latr. in einem Sarge. Zeit. $\dot{f}$. wiss Insektenbiol., 8, Heft 1, 32 . 